\title{
Partnership for improved access to agro-inputs and technology: Some experiences from the emergency rice initiative project in Ghana
}

\author{
W. Dogbe ${ }^{1}$, J. Sogbedji ${ }^{2}$, A. Mando ${ }^{2}$, S. S. J. Buah ${ }^{1 \star}$, S. K. Nutsugah ${ }^{1}$, R. A. L Kanton ${ }^{1}$, \\ I. D. K. Atokple ${ }^{1}$, A. Amankwah ${ }^{3}$, A. N. Wiredu ${ }^{1}$, A. S. Karikari ${ }^{1}$, K. Djamon ${ }^{4}$, C. Osei ${ }^{3}$, O. Ajayi ${ }^{5}$ \\ and K. Ndiaye ${ }^{6}$ \\ ${ }^{1}$ CSIR- Savanna Agricultural Research Institute (CSIR-SARI), P. O. Box 52, Tamale, Ghana. \\ ${ }^{2}$ IFDC, P. O. Box 1630, Accra, Ghana. \\ ${ }^{3}$ Catholic Relief Services-Ghana, Tamale Office, P. O. Box TL334, Tamale, Ghana. \\ ${ }^{4}$ Ghana Agro-dealer Development Project, C/o IFDC, Box 1630, Accra, Ghana. \\ ${ }^{5}$ AfricaRice Temporary Headquarters, Cotonou, Benin. \\ ${ }^{6}$ AfricaRice Sahel Station, St. Louis, Senegal.
}

Accepted 21 May, 2012

\begin{abstract}
A two-year emergency rice (Oryza sativa L.) initiative project was launched in 2009 in response to the global rice crisis in 2008. The objective of this initiative in Ghana was to increase rice productivity in order to improve food security. Project activities included seed fairs, dissemination of information on improved production technologies using videos and rural radios, training of agro-input dealers, extension officers and farmers as well as promotion of best-bet practices through field demonstrations. The project made progress in strengthening the ability of agro-input dealers to create business linkages with input suppliers and extend their retail networks to rice farmers. Overall, 34 agro-input dealers were trained, in collaboration with the Ghana Agro-dealer Development project, on agro-input business management, product knowledge and rice production. Thirteen agro-input dealers were assisted to access credit for business development. Better financed, trained agro-dealers were then able to provide over 12,600 rice farmers with improved seed, mineral fertilizers, technical advice on agro-input use and the promotion of improved agronomic practices through field demonstrations. Some agro-input dealers even provided free inputs for the conduct of demonstrations on new products and good agronomic practices. On average, fertilizer application in demonstration trials increased paddy yields by 68 to $80 \%$ over the farmer practice of no fertilizer application. For the participating farmers, there were significant increases in rice paddy yields, reductions in the cost of operations and improvements in the contribution of rice to household incomes. The results suggest that a holistic and multi-stakeholder partnership is an efficient way to improve the access by small-holder resource-poor farmers to agroinputs and technology and also an effective way to grow the rural agro-input market.
\end{abstract}

Key words: Subsidy, voucher, emergency, seed fair, improved-technology, fertilizer.

\section{INTRODUCTION}

Rice (Oryza sativa L.) is the second most important staple food after maize in Ghana and its consumption

\footnotetext{
${ }^{*}$ Correspondent author. E-mail: ssbuah@yahoo.com. Tel: +233244714217 .
}

keeps increasing as a result of population growth, urbanization and changes in consumer eating habits. Rice consumption, however, is significantly greater than domestic production, necessitating increased imports that drain huge amounts of scarce foreign exchange (Bam et al., 1998). Average annual rice consumption per capita in Ghana increased from $7.3 \mathrm{~kg}$ in the $1980 \mathrm{~s}$ to $22 \mathrm{~kg}$ in 
2003 when a total of 500,000 tonnes of rice was imported (ISSER, 2002). The self-sufficiency ratio for rice in Ghana is as low as 20 to $30 \%$. To achieve food security and foreign exchange savings, increased production of highly competitive domestic rice should be the utmost priority of Ghana's agriculture. Rice accounts for about $15 \%$ of agricultural GDP, and represents nearly $45 \%$ of total area planted to cereal grains.

It is widely acknowledged that poor soil fertility is the principal constraint to production in small-holder farming in Africa (Rhodes, 1995; Kaya et al., 2000; Hoffmann et al., 2001; Kent et al., 2001; AfricaRice, 2009). Moreover, most subsistence farmers in sub-Saharan Africa (SSA) use much less fertilizer than is economically optimal (Rhodes, 1995; Xu et al., 2009). On average, farmers in SSA use about $13 \mathrm{~kg}$ of fertilizer nutrients per hectare (ha) of arable land compared with the developing-country average of $94 \mathrm{~kg} / \mathrm{ha}$ (FAO, 2009). Subsistence farmers probably use too little fertilizer because they lack information on how to use fertilizer effectively and profitably, because they are risk-averse in the face of uncertain rainfall, or because they lack the cash to pay for it because of low income and poorly functioning credit markets.

Declining fallow periods, along with yield decline on soils exhausted from crop harvest without nutrient replacement, have resulted in a dramatic decline in soil fertility in the savanna agro-ecological zone of West Africa (Tarawali et al., 1999; DeGrassi and Rosset, 2002; Langyintuo et al., 2005; Xu et al., 2009). In addition to low inherent fertility, African soil nutrient balances are often negative, indicating that farmers mine their soils (Stoorvogel et al., 1993; Rhodes, 1995; Mafongoya et al., 2006). The farming systems currently used in Africa are unsustainable. Over the last three decades, agricultural productivity in Africa has generally declined and land degradation has increased. Because organic sources of nutrients are insufficient, low use of mineral fertilizers among small-holder farmers exacerbates soil nutrient deficiency and also causes environmental damage (Stoorvogel et al., 1993). Accelerated and sustainable agricultural intensification is required to feed the growing population. Yet intensification, increased agricultural productivity and improved rural livelihoods cannot occur without investment in soil fertility.

Development partners have in recent years called for governments to boost fertilizer use in Africa, with subsidies. In response to the need for higher fertilizer use in Africa, African policy-makers came together in 2006 at the African Fertilizer Summit in Abuja, Nigeria and resolved that member states should grant targeted subsidies in favor of the fertilizer sector (AU, 2006). The policy-makers believed that fertilizer subsidies are the only way to jump-start African agriculture and deliver concrete food security and income benefits to the rural poor. Member states therefore agreed to implement "smart subsidy" on fertilizer in order to make fertilizer increasingly available to small-holder farmers in member states. The "smart subsidy" is designed to target the poor and to support, rather than undercut, the development of private input distribution markets.

In 2009, a two-year short-term intervention Emergency Rice Initiative Project (ERIP) was launched as a direct response to the global food crisis and high rice prices experienced across West Africa in 2008. The project aimed to boost rice productivity and production and thereby improve the food security of farming households in four countries in West Africa (Ghana, Mali, Nigeria and Senegal).

The emergency initiative endeavored to boost rice production through enhancing farmer access to certified seed of improved rice varieties, mineral fertilizer and knowledge on best-bet rice technologies in the target countries.

The project was funded by the United States Agency for International Development (USAID) as a component of its Food Security and Crisis Mitigation Program. Globally, the project was led by the AfricaRice Centre (AfricaRice, ex-WARDA) and implemented in Ghana by the International Centre for Soil Fertility and Agricultural Development (IFDC), Catholic Relief Services (CRS), Council for Scientific and Industrial Research-Savanna Agricultural Research Institute (CSIR-SARI), Ministry of Food and Agriculture (MoFA) and the Ghana Agro-input Dealers Association (GAIDA).

In Ghana, the project was implemented in northern Ghana (comprising Northern, Upper East and Upper West regions) and targeted 10,000 resource-poor farmers. The objective was to boost total domestic rice production among the participating farmers by at least 30,000 tonnes of paddy rice in the country within the two years of the project.

The project also aimed at improving access for the 10,000 farmers to quality seed and mineral fertilizer while expanding their knowledge of appropriate and sustainable rice production technologies.

IFDC focused on the demonstration of best-bet fertilizer practices among participating farmers and facilitated linkages with other projects that focused on access to mineral fertilizers using the voucher system, as well as training of farmer organizations and the private sector on agribusiness management and marketing.

Strategies used by IFDC to improve access to mineral fertilizers for increased rice productivity included: (i) coordination of activities of actors and partners; (ii) creating demand for fertilizer at the farmer level; (iii) improving supply of fertilizer by input dealers; (iv) implementation of a fertilizer voucher scheme and (v) community outreach programs such as rural radio and video shows.

This paper summarizes the achievements of the project in improving the availability, accessibility and affordability of mineral fertilizers for the most vulnerable rice farmers and the lessons learnt based on the two-year experience. 


\section{MATERIALS AND METHODS}

Northern Ghana is the bread-basket of Ghana because of its high production potential for staple food crops- such as rice, maize,sorghum, pearl millet and yam- and the large rural farming population. Yet, northern Ghana is also the poorest region, with nearly two-thirds of the population living in poverty. Generally, northern Ghana often experiences hot, distinct dry and wet conditions. The characteristic unimodal rainfall regime starts from April or May and ends in October and ranges from an annual mean of 900 to $1,100 \mathrm{~mm}$. During the hot dry season (November to March), day temperatures can reach 30 to $37^{\circ} \mathrm{C}$, and the soils are regularly made bare by bush fires. The predominant soils in the area are savanna Glycols and Ochrosols derived from sandstone parent materials. As the soils are generally shallow with underlying iron pans, temporary water-logging as well as lack of moisture in the long dry season are common features. Low nitrogen $(\mathrm{N})$ and phosphorus $(P)$ levels limit crop production in this zone. Small-scale farmers predominate, but such farmers have few opportunities to intensify and commercialize their agricultural activities. For example, they have poor access to inputs, markets, low interest credit and extension services. Hence, there is little or no adoption of improved production technology and the low yields and rural poverty are further exacerbated.

The ERIP promoted the adoption of improved seed and mineral fertilizers as well as best-bet practices. The role of IFDC in improving the availability, accessibility and affordability of fertilizers for the most vulnerable rice farmers was achieved by (i) coordinating the activities of actors and partners through the organization of meetings/workshops and fertilizer sector studies; (ii) creating demand for fertilizer at the farmer level through farmer training and participatory on-farm demonstrations on nutrient management; (iii) improving the supply of mineral fertilizer by agroinput dealers by training them on product knowledge and business management; (iv) implementation of a fertilizer voucher scheme to improve the availability and access to mineral fertilizers for the most vulnerable rice farmers and (v) community outreach programs such as rural radio and video shows. These methods are reviewed in the sections that follow.

\section{Coordination of the activities of actors and partners and fertilizer sector studies}

A baseline study of the fertilizer value chain was conducted in 2009 in order to understand the functioning of the fertilizer market in the project area. The second part of the survey was conducted in partnership with the Ghana Agro-dealer Development (GADD) project to enumerate geo-referenced input dealer shops in the project area (Figure 1).

IFDC facilitated linkages among financial institutions, agricultural extension service providers, agro-input dealers, seed producers and farmers by organizing planning and review meetings annually. With this approach, the relevant stakeholders were able to collectively plan, implement, monitor and evaluate availability and access to agro-inputs at all times. The roles and responsibilities of each project partner were clearly spelt out during the inception of the project workshop.

\section{Creating demand for fertilizer at the farmer level}

Demand for fertilizer at the farmer level was created through media campaigns on the benefits of fertilizers, farmer trainings and demonstration of fertilizer materials and their management. Indirectly, the training and demonstrations were to create demand by making information available on how to use fertilizer effectively and profitably. Efforts were geared toward improving linkages between input dealers and farmers so as to bring fertilizer markets closer to farmers. The project also tried to improve farmers' access to credit. Members of the Seed Producers Association of Ghana (SEEDPAG) and participating farmers received training on mineral fertilizers and their management for improved efficiency.

Capacity building of agricultural extension agents (AEAs), farmers and agro-input dealers was a very important component of the project. Hence, IFDC organized three training-of-trainers (ToT) courses for AEAs, farmers and agro-input dealers in an effort to promote technology exchange and transfer. The training programs covered the voucher system and seed fairs, integrated rice management (IRM) practices and seed production techniques, inspection and certification. The training curriculum on IRM included optimal planting time, appropriate plant density, planting in rows, water management techniques, time of fertilizer application and the use of various fertilizers to improve soil fertility and rice paddy yields. In addition, the AEAs were trained on the protocol for field demonstrations and quality data collection procedures.

IFDC has demonstrated, over the years, the need for site-specific fertilizer recommendations and successfully tested integrated soil fertility management (ISFM) approaches in pilot communities. To further improve scaling-out of IRM and to increase impact, collaborative demonstration plots were set up with agro-input dealers, MoFA and farmers at the district level. On farmers' fields, incremental levels of $\mathrm{N}$ in the form of urea super granules (USG) were applied to rice to validate its use in comparison with granulated urea. The use of urea deep placement (UDP) technology coupled with various mineral fertilization schemes was extended into more than 15 communities.

In another demonstration trial, treatment combinations comprised compound fertilizer - NPK (15:15:15) or Actyva (NPK 23-10-5 +2 $\mathrm{MgO}+3 \mathrm{~S}+0.3 \mathrm{Zn}$ ) with urea or sulphate of ammonia. The compound fertilizer was used for basal dressing while urea or sulphate of ammonia was used for top dressing. These treatment combinations were applied to two parallel main plots that received foliar $(1.25 \mathrm{l} / \mathrm{ha}$ Boost xtra) or no foliar fertilizer. Overall, a total of 80 demonstrations were conducted across the three regions.

Compound fertilizer NPK is widely used in Ghana for basal dressing while urea and sulphate of ammonia are typically used for top dressing. On the other hand, Actyva, a compound fertilizer with micronutrients marketed by YARA, was largely unknown to farmers before the subsidy program. Actyva is known to minimize $\mathrm{N}$ losses while giving greater availability of soluble $P$ to rice over a wide range of soils compared to other NPK and straight fertilizers. A more efficient $\mathrm{N}$ source also means a reduced loss of nutrients to the environment. The demonstrations were visible to other farmers in the communities and field days were organized at different stages of crop growth in order to obtain feedback from farmers on the performance of the new technologies.

\section{Improving supply of mineral fertilizer by agro- input dealers}

IFDC developed best practices to improve the supply of mineral fertilizers to small-holder farmers by agro-input dealers and worked with financial institutions to promote innovative and enabling financial products. This helped to increase access and availability of fertilizers to the participating rice farmers. Additionally, IFDC developed multi-stakeholder and participatory approaches utilizing simple tools to facilitate innovation networks to share information and best practices, engage in policy dialogue and facilitate access to agro-inputs, technology and markets in the region. IFDC trained agro-input dealers on the basics of agro-input business management, product knowledge and rice production practices. Selected input dealers, AEAs and the Diocesan Development Officers (DDOs) were also trained to sensitize them on the project's 


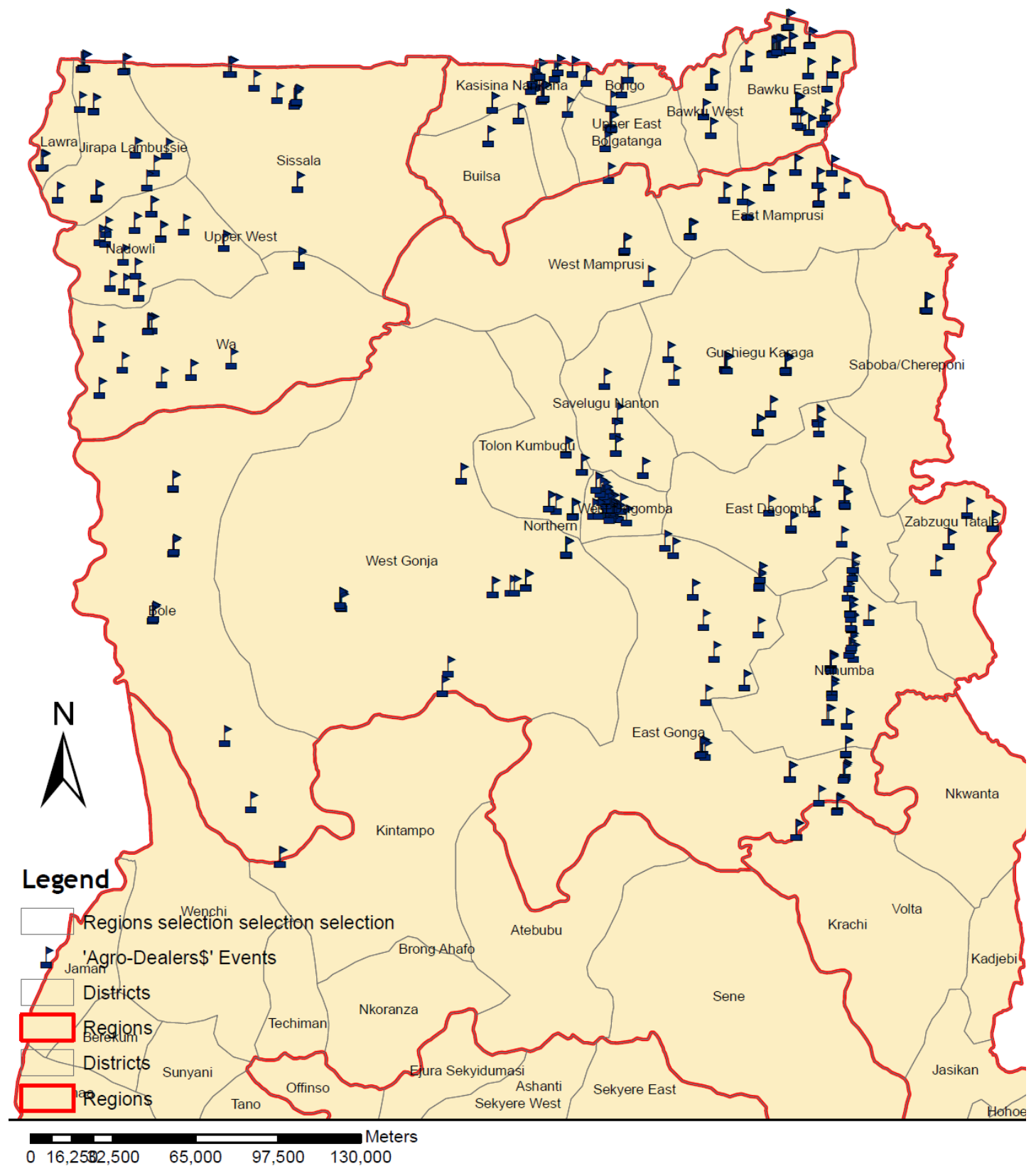

Figure 1. Location of agro-input dealers in Ghana, 2009 and 2010.

objectives, the input voucher scheme and the terms of partnership as well as agree on the roles of stakeholders in the planning and implementation of the demonstrations. Efforts were also made to improve linkages between agro-input dealers and financial institutions as well as between the agro-input dealers and farmers and other project partners.

\section{Implementation of a fertilizer voucher scheme}

In 2008, the government of Ghana introduced a $50 \%$ subsidy on fertilizer to make it affordable and increase fertilizer use, and to ensure a uniform price across the country. Below-market-cost provision of goods and services, generally by private-sector suppliers, from which the poor in particular are likely to benefit, can be regarded as smart subsidies. In 2009 and 2010, the subsidized prices for urea, NPK 15:15:15, NPK 23:10:05, and sulphate of ammonia were $\mathrm{GH} \$ 26, \mathrm{GH} \$ 26, \mathrm{GH} \$ 24$, and $\mathrm{GH} \$ 18$, respectively (exchange rate: $1 \mathrm{US} \$=\mathrm{GH} \$ 1.42$ ).

Furthermore, in 2009, CRS introduced an additional fertilizer subsidy program using the voucher (coupon) system. However, this scheme was not implemented in 2010. Rather than receiving free or subsidized seed or fertilizers directly, targeted rice farmers were given vouchers, which the farmers exchanged for inputs from a nearby dealer who had agreed to accept vouchers as payment. The input dealer in turn redeemed the vouchers for cash payment from 
the program organizers (that is, CRS). The voucher scheme included: (i) a mechanism for qualifying recipients and for distributing vouchers to them; (ii) a system for financing the distribution of inputs and for moving them through supply chains to qualified input dealers and (iii) a mechanism for managing the cash redemption of vouchers accepted by input dealers. Typically, the voucher system relied on existing commercial supply chains. The free vouchers were used to augment the fertilizer purchasing power of targeted farmers by reducing the price. Moreover, the vouchers were not quite equivalent to cash, because they were governed by rules established to meet specific program goals.

The vouchers were distributed to the farmers through the Diocesan partners and MoFA extension staff. The CRS voucher scheme relied on community-based targeting using poverty criteria. Thus, vulnerable farmers (very poor farmers) were issued coupons to purchase urea and compound fertilizers with a subsidy of 16 and $29 \%$, respectively in addition to the government subsidy of $50 \%$. The total subsidies translated to $69 \%$ (urea) and $79 \%$ (compound). On the other hand, viable farmers (relatively richer farmers) received a $29 \%$ subsidy (in addition to government subsidy) on compound fertilizer only but no additional subsidy on urea.

\section{Community outreach programs}

Community outreach programs included rural radio and video shows. These provided information and easy-to-learn ways of training. The videos were also translated into seven major local languages (Dagbanli, Gonja, Kusal, Kassim, Buli, Dagaari and Sissali) spoken in northern Ghana and effectively used by AEAs to train and convey important extension messages to farmers. The videos were also distributed to farmers, policy makers, local radio stations and MoFA district and regional offices in the three regions.

\section{RESULTS}

\section{Coordination of activities of actors and partners and fertilizer sector studies}

The baseline study revealed the actors in the fertilizer value chain, their roles, bottlenecks in the chain and ongoing initiatives to improve the chain. Results of the baseline study showed that all mineral fertilizer in Ghana is imported by private importers ready-for-use. Four private companies import essentially $100 \%$ of the fertilizers on the market. These importers, in order of market size, are Yara Ghana Ltd (subsidiary of Yara International ASA) and its partner cocoa fertilizer company Wienco Ghana Ltd; Golden Stork (subsidiary of SCPA Sivex International); Dizengoff Ghana Ltd (subsidiary of Balton CP Ltd); and Chemico Ltd. Chemico Ltd is the only large importer which does not have an international parent company. The loose fertilizer is placed in 50-kg bags in Tema and Accra and transported by road to distribution depots around the country. Importers frequently also distribute wholesale and retail fertilizer and sell bulk fertilizer to other private retailer who in turn sell to smaller retailers or directly to farmers.

Fertilizer wholesalers in northern Ghana included Iddisal Company, Wumpini Agrochemicals Company and Antika
Company. About 615 agents and independent input dealer shops are also found in the area (94 in Upper West region, 158 in Upper East region and 363 in Northern region) (Figure 1). Other actors identified are transporters, agricultural extension agents, research institutions (CSIR-SARI and University for Development Studies [UDS]) and farmers.

Major bottlenecks identified in the fertilizer value chain were: (i) delays and high rent charges which add up to the final cost of fertilizer for the resource-poor farmer these anomalies contributed up to $5 \%$ extra cost to the farmer; (ii) poor transportation and warehousing facilities; (iii) poor access to credit by wholesalers, retailers and farmers; (iv) weak fertilizer distribution networks; (v) inadequate quality control and regulation; (vi) limited product and technical knowledge of actors; and (vii) nonconsumer-friendly packaging (fertilizer is packaged in 50$\mathrm{kg}$ bags), a situation that is not appropriate for farmers who may need smaller quantities.

IFDC facilitated linkages among SEEDPAG members, foundation seed sources and agro-input dealers. Additionally, over 12, 600 farmers were linked to agroinput dealers in the project area (Table 1). Stakeholders in both seed and fertilizer value chains were sensitized on the project's objectives and roles and responsibilities of partners. Rice farmers were also linked to aggregators who supplied rice to the school feeding program, the National Buffer Stock Company (NAFCO) and the World Food Program (WFP). ERIP also collaborated with the Ghana Agro-Input Dealers Association (GAIDA), SEEDPAG, financial institutions (Ecobank and Stanbic Bank), aggregators (Amsig Resources Ltd.) and the media to increase access and availability of fertilizers to the most vulnerable rice farmers in the project areas.

\section{Creating demand for fertilizer at the farmer level}

The two-year project created demand for fertilizer at the farmer level and therefore improved the access by over 12,600 small-holder resource-poor farmers to quality seed and fertilizer while expanding knowledge of appropriate and sustainable rice production technologies (Table 1). Thirty-two percent $(32.4 \%)$ of the registered rice farmers in the project were women as they are more vulnerable. Over the two years, total paddy production was about 29,000 tonnes, representing almost 17,000 tonnes increase in production over what the farmers would normally have produced without the project's intervention. The 29,000 tonnes produced represented about $97 \%$ of the targeted total paddy production of 30,000 Tonnes. Buah et al. (2011) reported that the release and cultivation of early maturing and high yielding lowland and/or upland rice varieties in northern Ghana have aided the movement of rice into new frontiers, especially drought-prone areas in northern Ghana, and this resulted in increased rice productivity. Due to the 
Table 1. Target project sites and number of vulnerable rice farmers registered in Ghana, 2009 and 2010.

\begin{tabular}{lccc}
\hline Region & No. of farmers registered in 2009 & No. of farmers registered in 2010 & Total no. of farmers \\
\hline Northern & 1,630 & 3,102 & 4,732 \\
Upper East & 1,677 & 4,203 & 5,880 \\
Upper West & 914 & 1,248 & 2,162 \\
Total & 4,221 & 8,553 & 12,774 \\
\hline
\end{tabular}

Table 2. Fertilizer effect on rice paddy yield (kg/ha) in northern Ghana, 2009 and 2010.

\begin{tabular}{lc}
\hline Treatment & Treatment mean \\
\hline No fertilizer & 1807 \\
$250 \mathrm{~kg} / \mathrm{ha} \mathrm{NPK}+62.5 \mathrm{~kg} / \mathrm{ha}$ USG & 3207 \\
$125 \mathrm{~kg} / \mathrm{ha} \mathrm{NPK}+125 \mathrm{~kg} / \mathrm{ha}$ USG & 3383 \\
$250 \mathrm{~kg} / \mathrm{ha} \mathrm{Actyva}+62.5 \mathrm{~kg} / \mathrm{ha}$ Urea & 3471 \\
$125 \mathrm{~kg} / \mathrm{ha}$ Actyva $+125 \mathrm{~kg} / \mathrm{ha}$ Urea & 3180 \\
$250 \mathrm{~kg} / \mathrm{ha} \mathrm{NPK}+62.5 \mathrm{~kg} / \mathrm{ha}$ Urea & 3179 \\
$125 \mathrm{~kg} / \mathrm{ha} \mathrm{NPK}+125 \mathrm{~kg} / \mathrm{ha}$ Urea & 2895 \\
Mean & 3017 \\
LSD $(0.05)$ & 889 \\
\hline
\end{tabular}

USG $=$ Urea super granules; Urea $=46 \% \mathrm{~N} ; \mathrm{NPK}=15-15-15$ compound fertilizer, Actyva $=23$.

10-5-3-2-0.3 as N, P, K S, Mg and Zn; USG = Urea super granules; Foliar fertilizer = $1.25 \mathrm{l} / \mathrm{ha}$ Boost xtra.

ERIP intervention in northern Ghana, most farmers who participated in the program are now willing to pay for improved rice seed and fertilizer provided these inputs are accessible and affordable. Through on-farm demonstrations, best-bet fertilizer management practices have been identified and such information has been shared among various partners, project beneficiary farmers and farmers who were not directly involved in the project. Two of the management strategies relied on better $\mathrm{N}$ placement techniques and the use of controlledrelease fertilizers (in this case USG) to improve nutrient use efficiency in rainfed lowlands. Farmers in the region have started inquiring about the availability and accessibility of USG because they found it to be effective in increasing paddy yields as a result of increased $\mathrm{N}$ use efficiency.

Integrated nutrient management sought to enhance crop nutrition and minimize fertilizer costs. Averaging over basal and top dressed fertilizers, foliar application (1.25 $\mathrm{l} / \mathrm{ha}$ Boost xtra) produced $3086 \mathrm{~kg} / \mathrm{ha}$ of paddy yields while no foliar treatment produced $2940 \mathrm{~kg} / \mathrm{ha}$ of paddy yields. However, the difference in mean yield between foliar and no foliar treatments was not statistically significant hence data were averaged over foliar fertilizer treatments and the mean yield values for basal and top dressed fertilizers presented in Table 2. Over the years, mean paddy yields ranged from 1807 to 3471 $\mathrm{kg} / \mathrm{ha}$ when averaged over foliar fertilizer treatments. Mean paddy yields were lowest with the treatment with no fertilizer application (farmers' normal practice) while the highest yield was obtained from plots that received $250 \mathrm{~kg}$ Actyva plus $62.5 \mathrm{~kg}$ urea/ha and this was comparable to paddy yields from other treatments that received fertilizers (Table 2). On average, fertilizer application produced $80 \%(1445 \mathrm{~kg} / \mathrm{ha})$ more paddy than the unfertilized treatment. Among the fertilizer treatments, the least mean paddy yield $(2895 \mathrm{~kg} / \mathrm{ha})$ was recorded for $125 \mathrm{~kg}$ NPK plus $125 \mathrm{~kg}$ urea/ha. Visually, rice fertilized with Actyva produced plants that looked greener and had bigger panicles than unfertilized plants or those treated with NPK (15-15-15) fertilizer without the addition of micronutrients.

Results from nutrient omission trials conducted to find out the most limiting nutrients in rice production in the savanna zone showed that complete NPK fertilizer, on average produced the highest paddy yield of $3769 \mathrm{~kg} / \mathrm{ha}$ (Table 3). Mean paddy yield obtained from the complete NPK fertilizer was significantly greater than yields obtained from PK and no fertilizer treatments. The least paddy yield was obtained from the no fertilizer treatment (farmers' normal practice). Although the differences were not statistically significant, the application of both $\mathrm{N}$ and $\mathrm{P}$ tended to increase mean paddy yields when compared with PK only or no fertilizer treatment. On average, fertilizer application produced 68\% (1306 kg/ha) more paddy than the unfertilized treatment. Visually, fertilized plants were taller than unfertilized plants. Additionally, subsurface placement of both Actyva and NPK (15-15- 
Table 3. Nutrient omission effect on rice paddy yield $(\mathrm{kg} / \mathrm{ha})$ in northern Ghana, 2009 and 2010.

\begin{tabular}{lc}
\hline Treatment & Rice paddy yield $\mathbf{( k g / h a )}$ \\
\hline No fertilizer & 1913 \\
PK & 2668 \\
NK & 3192 \\
NP & 3247 \\
NPK & 3769 \\
Lsd $(0.05)$ & 1094 \\
\hline
\end{tabular}

No fertilizer $=0-0-0 \mathrm{~kg} / \mathrm{ha}$ as $\mathrm{N}, \mathrm{P}_{2} \mathrm{O}_{5}$ and $\mathrm{K}_{2} \mathrm{O} ; \mathrm{PK}=0-90-90 \mathrm{~kg} / \mathrm{ha}$ as $\mathrm{N}, \mathrm{P}_{2} \mathrm{O}_{5}$ and $\mathrm{K}_{2} \mathrm{O}$; $\mathrm{NK}=90-0-90 \mathrm{~kg} / \mathrm{ha}$ as $\mathrm{N}, \mathrm{P}_{2} \mathrm{O}_{5}$ and $\mathrm{K}_{2} \mathrm{O}$; $\mathrm{NP}$ $=90-90-0 \mathrm{~kg} / \mathrm{ha}$ as $\mathrm{N}, \mathrm{P}_{2} \mathrm{O}_{5}$ and $\mathrm{K}_{2} \mathrm{O} ; \mathrm{NPK}=90-90-90 \mathrm{~kg} / \mathrm{ha}$ as $\mathrm{N}$, $\mathrm{P}_{2} \mathrm{O}_{5}$ and $\mathrm{K}_{2} \mathrm{O}$.

15) gave about $40 \%(755 \mathrm{~kg} / \mathrm{ha})$ yield advantage over the broadcasting method of placement. Mean paddy yield of non-project farmers in this region was 1.25 t/ha. The mean paddy yield obtained by project beneficiaries in their production test plots across the three regions in Ghana was $1.94 \mathrm{t} / \mathrm{ha}$ in 2009 and $2.50 \mathrm{t} / \mathrm{ha}$ in 2010. These represented 55 and $92 \%$ increase over nonproject farmers' yields in 2009 and 2010, respectively. Across years and sites, unit production cost of rice was $\mathrm{GH} \$ 0.46 / \mathrm{kg}$ for non-project farmers and $\mathrm{GH} \$ 0.24 / \mathrm{kg}$ for project farmers. This represented $48 \%$ decrease in unit production cost for the project farmers. Moreover, the availability of good quality seed has promoted rapid diffusion and adoption of the early maturing and high yielding varieties in the region.

\section{Improving supply of mineral fertilizer by input dealers}

In 2009 and 2010, a total of 465 agro-input dealers in northern Ghana were trained in partnership with the GADD project and these dealers acquired skills in agroinput business management and product knowledge (Tables 4 and 5). Thirty-four of the trained agro-input dealers (30 males and 4 females) were linked to the ERIP and were able to open new retail shops closer to farmers in the rural areas to supply project farmers with inputs (especially improved rice seed and fertilizer). Thirteen out of the 34 agro-input dealers were able to access credit from the Alliance for a Green Revolution in Africa (AGRA) Guarantee Fund to expand their business (Tables 4 and 5). Participating agro-input dealers revealed that the project had helped them to increase their clientele and the volume of their business as well as qualifying them for higher levels of credit from financial institutions and business organizations.

We quote statements made by some agro-input dealers in the project area. Mr. Kwame Amoabe in the Builsa district in the Upper East region said:
"The project has benefited me and the farmers I was linked to. Before the project I was serving about 200 farmers a year. Since I was linked to project farmers in 2009, the number of farmers I serve and my business volume have increased. More than 400 farmers buy from me now. I have also benefited from the trainings and a credit package of GHC10, 000 which has helped me to expand my business. Some of the farmers said their paddy yields have doubled".

Madam Aisha Zakaria in the Tamale metropolis in the Northern region also added her voice when she said: "The linkage has given us a lot more customers and has increased our business volumes. Sometimes our farmers will call that they need inputs and we will send them to them. Because of my presence in the communities almost the entire community buys their agro-inputs from my shop. The increase in patronage facilitated our qualification for credit guarantee facility under the GADD project".

Furthermore the Director of Antika Company Ltd., Mr. Antiku Abdulai in the Upper West region said: "One big problem my business was facing was the poor product, crop and business knowledge for my agents. The project in partnership with the GADD project has helped to build the capacity of my agents in the districts. The linkage established with farmer groups has also increased my customer base and the volume of my business. Farmers we were linked to have reported very high yields with fertilizer use".

\section{Implementation of a fertilizer voucher scheme}

In 2009 , about 3,000 poor small-holder farm families in the project area (constituting $71 \%$ of the total registered farmers) benefited from the voucher system (Table 5). All the 4,221 registered farmers in 2009 could not access fertilizers because of unavailability of fertilizers in some parts of the region during planting time when it was most needed. The voucher scheme for the vulnerable and viable farmers involved free seed to plant 0.2 hectare and urea and compound fertilizers subsidized at 69 and $79 \%$, respectively.

A total of 150 tonnes of fertilizer was distributed to beneficiary households in 2009. The voucher scheme was implemented to attain the twin objectives of intervening in the market with fertilizers for beneficiary farmers, involving the private sector dealers, and helping the market to grow. The scheme was designed to run for only a year, hence the subsidy was removed by CRS in 2010 and farmers and input dealers were expected to make the transition to an economically sustainable cash market. All the 8,553 farmers registered in 2010 were linked to agro-input dealers to access fertilizers. About 4,500 of the farmers (representing $53 \%$ of the registered farmers) actually procured and applied fertilizers to their rice farms. It seems the voucher system applied in 2009 
Table 4. Major activities organized by the IFDC to promote technology transfer, 2009-2010.

\begin{tabular}{|c|c|c|}
\hline Activity & Output & $\begin{array}{l}\text { Potential impact on technology } \\
\text { transfer }\end{array}$ \\
\hline $\begin{array}{l}\text { Facilitate baseline survey on agro-input } \\
\text { market, credit institutions and FBO's in the } \\
\text { project area. }\end{array}$ & $\begin{array}{l}\text { Survey conducted in partnership with } \\
\text { the GADD project in the three project } \\
\text { regions. }\end{array}$ & $\begin{array}{l}\text { Directory of agro-input dealers in the } \\
\text { project districts and a database and GIS } \\
\text { locations for agro-input dealers made } \\
\text { available. }\end{array}$ \\
\hline $\begin{array}{l}\text { Organize agro-input dealer training in agri- } \\
\text { business development and management. }\end{array}$ & $\begin{array}{l}\text { Total of } 465 \text { agro-dealers were trained } \\
\text { in partnership with the GADD project. } \\
34 \text { of them linked to the ERIP. }\end{array}$ & $\begin{array}{l}\text { Enhanced product and business } \\
\text { knowledge which contributed to } 38 \% \text { of } \\
\text { them qualifying for credit to expand their } \\
\text { business. }\end{array}$ \\
\hline \multirow{3}{*}{$\begin{array}{l}\text { Facilitate linkages among credit } \\
\text { institutions, seed producers, agro-input } \\
\text { dealers, other projects and FBO's to } \\
\text { enhance Farmer/FBO access to seed and } \\
\text { fertilizer using the input voucher system. }\end{array}$} & $\begin{array}{l}\text { - SEEDPAG linked to foundation seed } \\
\text { source and to agro-input dealers }\end{array}$ & \multirow[b]{2}{*}{$\begin{array}{l}\text { - The linkage created ready market for } \\
\text { SEEDPAG members. } \\
\text { - } 34 \text { input dealers opened new shops } \\
\text { closer to farmers. } \\
\text { - Increased stock levels and customer } \\
\text { base and profit margins for dealers. }\end{array}$} \\
\hline & $\begin{array}{l}\text { - Out of the } 34 \text { agro-input dealers } \\
\text { linked to the project } 13(38 \%) \text { were } \\
\text { able to receive credit from the AGRA } \\
\text { guarantee fund to improve their } \\
\text { business }\end{array}$ & \\
\hline & $\begin{array}{l}\text { - A total of } 12,774 \text { Farmers linked to } \\
\text { agro-dealers to access seed and } \\
\text { fertilizer }\end{array}$ & $\begin{array}{l}\text { - Increased fertilizer use has contributed } \\
\text { to an increased yield of between } 40-97 \%\end{array}$ \\
\hline Coordinate input distribution system. & $\begin{array}{l}\text { Stakeholders in both seed and fertilizer } \\
\text { value chains were sensitized on } \\
\text { project objectives and roles of } \\
\text { partners. Follow up reminders and } \\
\text { meetings were held. }\end{array}$ & $\begin{array}{l}\text { Enhanced project implementation and } \\
\text { achievement of targets. }\end{array}$ \\
\hline $\begin{array}{l}\text { Facilitate the use of radio, video and } \\
\text { public fora to educate farmers. }\end{array}$ & $\begin{array}{l}200 \text { Rice video's distributed to agro- } \\
\text { dealers, project partners and watched } \\
\text { by aver } 15,000 \text { farmers. }\end{array}$ & $\begin{array}{l}\text { - Increased awareness of the project } \\
\text { objectives and outcomes. } \\
\text { - Facilitated the exchange of information } \\
\text { on available best-bet rice production } \\
\text { practices. }\end{array}$ \\
\hline $\begin{array}{l}\text { Facilitate the use of PLAR-IRM for FBO } \\
\text { training in Best bet fertilizer management } \\
\text { practices. }\end{array}$ & $\begin{array}{l}\text { Demonstration on USG technology } \\
\text { and other new fertilizer materials } \\
\text { planted across the } 3 \text { project regions for } \\
\text { training purposes. }\end{array}$ & $\begin{array}{l}\text { Farmers have started requesting for some } \\
\text { of the new products like USG and NPK } \\
(23-10-5) \text {. }\end{array}$ \\
\hline $\begin{array}{l}\text { Facilitate linkages for setting up rice } \\
\text { business market. }\end{array}$ & $\begin{array}{l}\text { Links have been established with } \\
\text { aggregators who supply rice to the } \\
\text { school feeding program, the National } \\
\text { Buffer stock company and WFP. }\end{array}$ & $\begin{array}{l}\text { Companies like the AMSIG Resources } \\
\text { Ltd, Edem Farms Ltd and the Sunlo Co. } \\
\text { were linked to project communities where } \\
\text { they bought rice from project farmer. }\end{array}$ \\
\hline
\end{tabular}

raised farmers' expectations towards similar subsidies in 2010 and this reduced the purchase rate of full-priced fertilizer even in view of the discontinuation of the voucher project.

\section{Community outreach programs}

Two hundred copies of the English version of videos on key rice management practices from land preparation to harvest and post-harvest activities were distributed to farmers and extension staff in the various regions. Both the English and local language versions of the videos have been watched by over 15.000 farmers in northern Ghana. Additionally, the videos were used to train extension volunteers. For example, in a gender-sensitive approach to extension 
delivery, the Dagaari version of the videos was used to train 55 female extension

4798 Afr. J. Agric. Res.

Table 5. Indicators, targets and achievements of the ERIP in Ghana, 2009 and 2010.

\begin{tabular}{|c|c|c|c|}
\hline Indicator & 2009 & 2010 & Total (achievement) \\
\hline No. of registered farmers & 4221 & 8553 & 12774 \\
\hline No. of agro-dealers trained & 105 & 360 & 465 \\
\hline No. of agro-dealers linked to project & 34 & 33 & 34 \\
\hline No. of farmers linked to agro-dealers & 3000 & 4500 & 7500 \\
\hline No. of agro-dealers who participated in seed fairs & 10 & 5 & 15 \\
\hline${ }^{*}$ No. of agro-dealers who accessed credit & 8 & 5 & 13 \\
\hline \multicolumn{4}{|l|}{ No. of demonstrations conducted } \\
\hline Urea deed placement & - & 30 & 30 \\
\hline Nutrient omission trials & - & 12 & 12 \\
\hline Others & 38 & - & 38 \\
\hline No. of field days organized & 20 & 65 & 85 \\
\hline \multicolumn{4}{|l|}{ Impact among sampled farmers } \\
\hline Average yield (tonnes/ha) & 1.94 & 2.5 & $100 \%$ \\
\hline \multicolumn{4}{|l|}{ Baseline $=1.25$ tonnes $/$ ha } \\
\hline Average operations cost (USD/kg) & 0.30 & 0.24 & $48(\%)$ \\
\hline \multicolumn{4}{|l|}{ Baseline $=\mathrm{GHc} 0.46 / \mathrm{kg}$} \\
\hline Share of rice income (\%) & 29 & 33 & $22(\%)$ \\
\hline Baseline (27\%) & & & \\
\hline
\end{tabular}

'-'not available*, Access to credit was facilitated by ERI and GADD projects.

volunteers in two districts in the Upper West region. This is particularly important because the male extension staff, on religious grounds, may not be permitted to meet with wives of some farmers.

Through rural radio and video shows, current rice production technologies are also reaching thousands of rice producers who were not directly involved in the project. Four project beneficiary farmers were awarded prizes for being the best rice farmers at regional and district levels during the National Farmers' Day celebrations in 2009 and 2010.

\section{DISCUSSION}

The Emergency Rice Initiative project implemented multistakeholder and participatory approaches utilizing simple tools to facilitate innovation networks to share information and best practices, to engage in policy dialogue and to facilitate access to inputs, technology and markets in the country. It facilitated the establishment of linkages among stakeholders in the rice value chain that ensured the sustainability of the gains from the project. One important achievement of this project is the formal linking of project farmers to agro-input dealers to access inputs. Hitherto, most projects supplied inputs directly to farmers. This formal linkage, according to testimonies from both farmers and agro-input dealers, has fostered very close relationships between project farmers, their communities and agro-input dealers they were linked to. This system has the potential of convincing project beneficiaries that inputs or project supports are not from government and this may result in better credit payment. Non-repayment of credit by farmers is an endemic problem for most government supported projects.

Generally, the project enhanced human capital and social organization and developed individual and collective capacities of farmers and agro-input dealers to adopt and adapt innovative practices using technologies and managerial and marketing skills. These linkages also allowed small-holders and producer organizations to interact with other members of the agricultural sector within established innovation networks.

Improved access to credit in order to purchase agroinputs is particularly important. However, linkage to credit was rather difficult and frustrating as many lenders are extremely wary of extending credit to farmers, fearful that they will inherit the risks inherent in farming. IFDC concentrated on the technical capacity of Farmer Based Organizations (FBOs) and the agro-input dealers that it worked with. Experiences in working with these two actors have revealed weak organizational and financial capabilities of these actors, especially the FBOs. The weak organizational capacity explains the difficulty in linking FBOs, especially the targeted group (vulnerable farmers) for credit. 
Fertilizer market development is an alternative approach to improving farmers' access to fertilizer. This for the development of site-specific recommendations. In addition, targeted training equipped extension staff, Dogbe et al. strategy involves improving the policy environment, strengthening and expanding the network of private agroinput dealers with training and credit, and providing farmers with better information on how to make productive use of fertilizers through advisory services and demonstration plots. As soils in SSA are inherently low in plant available nutrient, the single most significant factor likely to influence agricultural sustainability in the region is accessibility to fertilizer. Results showed that to maximize the gain in productivity of rice farmers in favorable environments, farmers need to have improved access to mineral fertilizers.

It seems that if mineral fertilizer is readily available and affordable, farmers who have been trained in advanced technologies are highly likely to continue to use it. However, the distribution of fertilizers, access and affordability by small holders remains a fundamental policy challenge. The high cost of fertilizer prevents particularly resource-poor farmers from using the required levels of fertilizer to boost crop production (Rhodes, 1995). Nonetheless, results showed that low-input farmers are likely to adopt new production systems that significantly increase household food self-sufficiency and/or farm income. In addition, productivity in rice systems can be further enhanced by improving the efficiency of fertilizer use. In general, paddy yields increase was $55 \%$ in 2009 and $92 \%$ in 2010 when compared to the farmers' normal practice of growing rice without fertilizer application. Increases in yield could also increase the amount of organic matter returned to the soil through roots and potentially through crop residues. Results also showed that USG could increase $\mathrm{N}$ use efficiency in rice production. Nevertheless, additional application of foliar fertilizer did not increase paddy yields significantly. It is worthy of note that foliar fertilizer alone is not enough for optimum paddy yield because the amount of NPK supplied in the foliar fertilizer is not adequate for optimum paddy yields. Moreover, the greatest difficulty in supplying $\mathrm{N}, \mathrm{P}$, and $\mathrm{K}$ in foliar sprays is in the application of adequate amounts without severely burning the leaves and without an unduly large volume of solution or number of spraying operations.

Low level of fertilizer application in SSA indicates a substantial scope for potential yield increases. Generally, the application of $\mathrm{N}$ and $\mathrm{P}$ fertilizers has proved to have a good effect on rice production in the region and these two nutrient elements seem to be the most limiting nutrients for rice production in the region.

The ERIP was designed to strengthen the capacities of agricultural service providers, such as research institutions, government extension officers, agro-dealers, NGOs, micro-finance institutions and producer organizations involved in the rice value chain. The project developed the capacities of local participants to use participatory and systems approaches, which are required farmers and input dealers with the knowledge to establish linkages, conduct joint input procurement, negotiate input prices and form innovation clusters.

The ERIP approach has shown that existing rice technologies can substantially increase paddy yields per unit area and also reduce unit production costs among rice farmers. Results of the impact studies revealed that the use of quality seeds and fertilizers doubled rice productivity among collaborating farmers from about 1.25 tonnes/ha in 2008 to about 2.5 tonnes/ha in 2010 . This resulted in about $48 \%$ reduction of the unit cost of rice production. Significant increases were also recorded for the contribution of rice to household income. On the average, the contribution of rice to household income increased to 29\% in 2009 and $33 \%$ in 2010. Thus, existing rice technologies can substantially increase paddy yields per unit area and also reduce unit production costs among rice farmers.

The reduction in unit production costs may be attributed to a technical change as farmers adopted improved seeds, fertilizers and production technologies, leading to higher paddy yields. Several project farmers attributed the yield increases to the use of improved seed and fertilizers. Hitherto, most farmers in this area planted their own-saved rice seed with little or no fertilizer input. Most of the farmers said that the rice from their production test plots would be used to address household food security. A portion of the grain would, however, be sold to raise funds to pay school fees and purchase fertilizers for rice production in the next season.

The voucher system of fertilizer distribution to vulnerable farmers proved to be very useful and provided a win-win situation for both the farmers and the agroinput dealers. The scheme enabled agro-input dealers to partner with farmers and AEAs in the distribution of fertilizers to farmers. Even though no fertilizer vouchers were issued in 2010, the effect of the voucher system lingered even in the second year. Most farmers who participated in the program in 2009 sold their paddy rice and used the proceeds to buy fertilizer for use in rice production in 2010. Although farmers in certain parts of the project area do use fertilizer for rice production, the amounts of fertilizers used are limited for a variety of reasons. First of all, cash is often lacking at the time of planting due to competing demands for other household needs, such as food or school fees. This means that even if the fertilizer price is lowered, there may still be a problem with access to cash when needed. Initiatives to provide fertilizers in small packs, which are more within the reach of farmers' budgets, may lead to more widespread use of fertilizer.

The voucher-based system enabled the private sector to be a major player in all marketing and distribution activities. ERIP distributed fertilizers through local fertilizer retail outlets instead of distribution of pre- 
packaged fertilizers, thereby increasing availability of fertilizer at the retail level. Reports from southern Africa $4800 \quad$ Afr. J. Agric. Res.

indicate that direct input distribution, such as the starter packs, has minimal impact on enhancement of household discretionary cash and rice production (Bramel and Remington, 2003, 2005; Longley et al., 2006). Moreover, direct input distribution does not allow the private sector to expand its retail distribution networks countrywide into the rural areas, as is apparent in Ghana where the private sector normally operates only in urban and periurban areas. Experience in some countries has shown that direct input distribution is costly to government and is more susceptible to pilferage and fraud compared to the voucher-based systems (Longley et al., 2006). Thus, the innovative voucher system introduced in 2009 has been responsive in improving small-scale farmers' access to fertilizer as a result of reduced cost. It has also led to increased production and yield levels, as well as enhanced farmers' welfare.

The use of vouchers as part of a "demand-pull" strategy to promote increased fertilizer use has several potential advantages as the vouchers could be used to target specific groups of farmers. In our case, we targeted farmers who fall into a particular social stratum or income class (very poor class). Results obtained over the years demonstrated that vouchers can build additional demand for fertilizer and thus accelerate fertilizer market development if the targeted farmers are not already using fertilizer. The voucher scheme was thereforeseen and utilized by the commercial input dealers as a means to increase their market outreach. Through local input agents at fairs, the input dealers had great opportunities to reach more farmers and thus increase their sale of seed and fertilizers. Studies in eastern and southern Africa have also revealed such likely outcomes from the use of vouchers (Bramel and Remington, 2003, 2005). Most farmers in northern Ghana were hitherto growing rice with little or no fertilizer input. With the voucher system, there has been an expansion in the number of small-holder farmers using fertilizer. Thus, it is likely that the increase in fertilizer use did not come from the same farmers who used fertilizer prior to the program.

A key strength of the voucher system was the use of AEAs to distribute the vouchers, a choice that was smart and innovative for several reasons. The AEAs are supposed to be in contact with farmers and should, therefore, know the true farmers as opposed to impostors, who would want to abuse the program by obtaining and reselling the fertilizer. Using the AEAs to distribute the vouchers also had the potential of minimizing the use of the program as an instrument of political patronage. Also, the use of AEAs minimized power-peddling and constrained local political/party patrons from hijacking, politicizing, or abusing the program for political or personal gains. More so, tying voucher distribution to the operational areas of $A E A s$ minimized favoritism and made the coupons highly accessible to farmers. It also increased the respect for

AEAs, intensified interactions, and improved relations between farmers and their AEAs.

As no farmer benefited from the CRS voucher system in $2010,47 \%$ of the participating farmers did not use any fertilizer, citing high cost and limited accessibility as main reasons. The decrease in the percentage of participating farmers who used fertilizer $(71 \%$ in 2009 as against $53 \%$ in 2010) could be attributed to the termination of the voucher system and the disincentive to purchase unsubsidized fertilizer from the fertilizer retailers in the open market. This suggested that the anticipation of cheaper fertilizer actually lowered the motivation of farmers to purchase unsubsidized fertilizer, even when the subsidized fertilizer was not available at the time of planting. The reduction in the use of fertilizer could also be attributed to the actual shortage of the familiar compound fertilizer (NPK: 15-15-15) in the subsidy program in the project area. This has detrimental consequences for rice production, the fertility subsidy program and the fertilizer market.

Although the project succeeded in increasing rice production in the area, it was nonetheless, faced with the challenges of pushing up the rice yield curve. Furthermore, the efficiency in the fertilizer subsidy program was marred by logistical difficulties. Late importation of fertilizer often leads to delayed distribution to farmers throughout the country; in some cases the fertilizer arrived at post-application stages of the crop. Delay in fertilizer application could reduce the effectiveness of the fertilizer. It is likely that the delay in availability of fertilizer is also attributable to the narrow focus on price policy without sufficient consideration for the distribution system (Heisey and Mwangi, 1996). Access to fertilizer is still a problem for most farmers in the country. Despite the $50 \%$ government subsidy and increased availability of mineral fertilizer, the cost of fertilizer is still considered high especially for most of the targeted vulnerable farmers. For such farmers, further subsidy similar to that provided by CRS in 2009, is absolutely necessary. In general, farmers in Ghana have expressed their appreciation for the government fertilizer subsidy program. They conceded that the smart subsidy on fertilizers is essential and needs to be continued. Moreover, the farmers are urging government to consider increasing the rate of subsidy above $50 \%$. They also want the subsidy to be extended to cover improved seed. Low fertilizer use efficiency still remains a challenge in most farms, mainly as a result of delays in field operations. Through training, farmers now understand the importance of timely field operations to improve fertilizer use efficiency but they have no control over when equipment for their field operations will be available.

The use of voucher programs has some potential disadvantages. Voucher programs can be costly to design and implement, particularly if subsidies are 
involved that entail special measures to minimize corruption. Additionally, voucher programs can fail to promotion of fertilizer use through the mass media and demonstrations by agro dealers is on-going; (v) A Dogbe et al. achieve their objectives if convertible vouchers are purchased by intermediaries and a secondary market emerges for their resale and use.

The successes of the ERIP could be integrated into the national rice program (e.g. Block Farm Program, and emerging new rice projects and initiatives). A key achievement of the ERIP is the formal linking of farmers to agro-input dealers to access inputs. The Block Farm Program, the Rice Sector Support Project (RSSP) and other emerging rice projects can take a cue from the experience of the ERIP and link farmers to input and other service providers instead of directly providing these services. In the case of the Block Farm Program, this would take the burden off the AEAs who will have to directly distribute fertilizer to farmers and also recover produce at the end of the season. Moreover, this direct input distribution system is not only costly to government but is also susceptible to pilferage and fraud compared to the voucher-based system.

There is the need to strengthen organizational and business capacity of FBOs. Because it is impractical for any aggregator/marketer to directly interact with several thousands of small-holder farmers at a time, aggregation and collective action are critical. It is therefore important to build the capacity of FBOs in collective action, to see farming as a business, and to assist them to develop business plans and set targets. Well organized FBO's can then be linked with aggregators or end-market small and medium scale enterprises (SMEs) of their choice for the purpose of managing the supply of produce. Such a capacity building and linkage will enhance their ability to access credit to expand or improve their operations.

Increased access of farmers to equipment services is paramount to sustaining achievements by the project in increased productivity and efficiency of mineral fertilizer use. There is currently a general lack of appropriate simple motorized planters, reapers and threshers to support farmers. The few combine harvesters currently in use are not suitable for small isolated farms that are dispersed over vast distances. Although the Agricultural Mechanization Service Centres being promoted in the districts by government are laudable, they are woefully inadequate. There is the need to assist SMEs to set up more machinery and equipment service centres. The service centres should be equipped to render all forms of mechanized services to farmers from land preparation through planting and harvesting to bagging and storage.

Currently, there are some on-going initiatives in the country to improve the fertilizer value chain: (i) IFDC and GAIDA are implementing the GADD project which aims at enhancing the technical and financial capacity of agrodealers; (ii) Registration and mapping of agro-dealers are on-going; (iii). Government introduced a 50\% fertilizer subsidy program in 2008 in line with the Abuja declaration to promote fertilizer use; (iv) Intensive fertilizer and plant bill has been passed by the parliament of Ghana.

Our experience over the two years of the project shows that a multi-disciplinary systems analysis approach to prioritizing and removing rice production constraints is of paramount importance. Policies that would provide conducive environments for rapid adoption and utilization of sustainable technologies must be put in place. The government and policy makers should seriously look into important policy issues relating to rice production. The intervention should consider inputs such as fertilizer, trade, marketing and product utilization if the full potential of rice is to be achieved in the country.

\section{Conclusion}

The project increased vulnerable farmers' technical knowledge on rice production and also strengthened partnerships among farmers' organizations, researchers, agricultural extension officers, the private sector and NGOs. It also increased rice productivity in the country. The subsidy program made fertilizer available and accessible to small-holder rice producers in the project area.The project improved the livelihoods of participating poor farmers in northern Ghana through improved land husbandry and better access to, and more efficient use of fertilizers. Training of farmers on improved integrated rice management practices using rural radios and videos will have a lasting effect on farmers' productivity and the quality of the environment. This effect will be especially viable in lowland rice systems. Sustainability of the gains of the project's intervention is assured through farmers producing their own seed, farmer-to-farmer exchange of seed and knowledge, adoption of improved seed and production technology by farmers, farmers' willingness to buy seed and fertilizer, national rice initiatives and the linkages established by the project among stakeholders in the rice value chain. There is a need for a review of all aspects of fertilizer accessibility, including private and public sector distribution, partnerships and subsidy practices, and the development of a program that facilitates accessibility to improved technologies and input distribution. We suggest that the government and development partners should address the lack of capacity of national extension services to implement new approaches to fertilizer use or facilitate timely access to agro-inputs. Strong partnerships and strategic planning that bring improved inputs, access to finance and farm management skills to farmers could significantly increase paddy yields.

\section{ACKNOWLEDGEMENTS}


The contribution of ERIP partners, including IFDC, SARI, MoFA, CRS, GAIDA, AfricaRice and collaborating 4802 Afr. J. Agric. Res.

farmers, is highly acknowledged. The authors are also grateful to USAID for the financial support to AfricaRice for the activities reported in this paper.

\section{REFERENCES}

AfricaRice Centre (AfricaRice) (2009). Annual Report (2009).Increasing investment in Africa's rice sector. Cotonou, Benin. p.68.

African Union (AU) (2006). Abuja declaration on fertilizer for the African Green Revolution. Declaration of the African Union Special Summit of the Heads of State and Government, June 13, Abuja, Nigeria.http://www.africafertilizersummit.org/Abuja\%20Fertilizer\%20 Declaration\%20in\%20English.pdf.

Bam RK, Anchirinah VM, Manful JJ, Ansereh-Bio F, Agyemang A (1998). A Preliminary Study of Consumer Preferences and Price. Natural Resources Institute (NRI), Project Report No. 34, Project 6688, UK

Bramel P, Remington T (2003). Relief Seed Assistance in Ethiopia. A case study done by CARE Norge and CARE Ethiopia funded by Ministry of Foreign Affairs-Norway. Final Report.

Bramel PJ, Remington T (2005). CRS Seed Vouchers and Fairs: A Meta-Analysis of their Use in Zimbabwe, Ethiopia and Gambia. CRS East Africa, Nairobi.

Buah SSJ, Nutsugah SK, Kanton RAL, Atokple ADK, Dogbe W, Karikari AS, Wiredu AN, Amankwah A, Osei C, Ajayi O, Ndiaye K (2011). Enhancing farmers' access to technology for increased rice productivity in Ghana. Afr. J. Agric. Res. 6:4455-4466. Available online http://www.academicjournals.org.

DeGrassi A, Rosset P (2002). A New Green Revolution for Africa?: Myths and Realities of Agriculture,Technology, and Development. Institute for Food and Development Policy, Oakland, CA, USA (Food First).

Food and Agriculture Organization of the United Nations (FAO) (2009). FAOStat. http://faostat.fao.org/site/422/default.aspx\#ancor.

Heisey PW, Mwangi W (1996). Fertilizer Use and Maize Production in Sub-Saharan Africa.CIMMYT Economics Working Paper 96-01, Mexico D.F.

Hoffmann I, Gerling D, Kyiogwon U, Mane-Bielfedt A (2001). Farmers' management strategies to maintain soil fertility in a remote area in northwest Nigeria. Agric. Ecosyst. Environ. 86:263-275.

Institute of Statistical, Social and Economic Research (ISSER), (2002). The State of the Ghanaian Economy in 2001.ISSER, University of Ghana, Legon, Accra, Ghana.

Kaya B, Hilderbrand PE, Nair PKR (2000). Modeling changes in farming systems with the adoption of improved fallows in southern Mali. Agric. Syst. 66:51-68.
Kent R, Johnson DE, Becker M (2001). The influences of cropping system on weed communities of rice in Côte d'Ivoire, West Africa. Agric. Syst. 87:299-307.

Langyintuo AS, Yiridoe EK, Dogbe W, Lowenberg-Deboer J (2005). Yield and income risk efficiency analysis of alternative fallow systems for rice production in the Guinea Savannah of Northern Ghana. Agric. Econ. 32:141-150.

Longley C, Kachule R, Madola M, Maposse I, Araujo B, Kalinda T, Sikwibele $\mathrm{H}(2006)$. Agricultural input vouchers in Southern Africa: Synthesis of research findings from Malawi, Mozambique and Zambia. Food, Agriculture and Natural Resources Policy Analysis Network (FANRPAN) http://www.fanrpan.org/documents/d00236/Agricultural_Input Vouch ers_SA.pdf.

Mafongoya PL, Bationo A, Kihara J, Waswa BS (2006). Appropriate technologies to replenish soil fertility in southern Africa. Nutrient. Cycling in Agroecosystem 76:137-151. doi:10.1007/s10705-0069049-3.

Rhodes ER (1995). Nutrient depletion by food crops in Ghana and soil organic nitrogen management. Agric. Syst. 48:101-118. DOI: 10.1016/0308-521X(95)93648-W

Stoorvogel JJ, Smaling EMA, Janssen BH (1993). Calculating soil nutrient balances in Africa at different scales. Fert. Res., 35:227-235. DOI: 10.1007/BF00750641

Tarawali G, Manyong VM, Carsky RJ, Vissoh PV, Osei-Bonsu P, Gariba $M$ (1999). Adoption of improved fallows in West Africa: lessons from mucuna and stylo case studies. Agrofor. Syst. 47:93-122.

Xu Z, Burke WJ, Jayne TS, Govereh J (2009). Do input subsidy programs "crowd in" or "crowd out"commercial market development? Modeling fertilizer demand in a two-channel marketing system. Agric. Econ. 40:79-94. 